\title{
Uma análise discursiva sobre a autoria de A Ciência na Cozinha e a Arte de Comer Bem, de Pellegrino Artusi
}

\section{A discursive analysis on the authorship of the book Science in the Kitchen and the Art of Eating Well, by Pellegrino Artusi}

Carla Maicá Silva ${ }^{1}$

A gastronomia é sem dúvidas um dos elos mais fortes de um povo. Nela, identidade e cultura são expressas através de práticas alimentares. Inscrita na Análise do Discurso francesa, compreendo tais práticas como discursos. Ao tratar a gastronomia e os discursos sobre por tal perspectiva, abordo a face política dessas práticas, as relações de forças que estão implicadas nelas, os conflitos e a constituição dos sujeitos a partir desses modos e saberes. Assim, ao tomar como objeto de pesquisa o livro de culinária considerado um dos pilares da construção identitária italiana pós-unificação, o tomo como uma materialidade significante.

O livro A Ciência na Cozinha e a Arte de Comer Bem foi escrito e publicado por Pellegrino Artusi em 1891 - trinta anos após a unificação - e acrescido e reeditado por vinte anos, graças à relação epistolar mantida entre autor e leitores. Enquanto o Estado investia na tentativa de consolidar a Itália como nação, Artusi, um senhor burguês de 70 anos, diletante, patriota, liberal e anticlerical, chegava aos lares de muitos desses "novos italianos" quase que sorrateiramente com uma linguagem técnica, clara e eficaz, mas nem por isso monótona. Com a grande circulação de seu manual prático para as famílias o autor foi capaz de apresentar a Itália aos italianos através não somente de receitas, mas também de observações pessoais que ficam entre a etnologia e a picuinha, entre a descrição e a interpretação, em um movimento complexo de autoria que, ao mesmo tempo em que sistematizava a terminologia culinária, gerando um efeito de unidade através da língua, salientava as diferenças entre as regiões apontando particularidades dos dialetos e das mentalidades. Seria, então, a primeira tentativa de reconhecimento nacional, de uma unidade que se construiu a partir das diferenças: a unidade na dispersão, a alteridade para se constituir como um.

A partir das quinze edições do livro e das correspondências encontradas em Pellegrino Artusi e la cucina di casa, de Martina Fabretti (2008), analisei a constituição do receituário suspendendo as evidências simbólicas tanto sobre a figura do autor quanto da obra também conhecida como $O$ Artusi. A realização do estudo permitiu compreender a particularidade da autoria - a qual categorizo como autoria bumerangue - e também a descrição de um estilo e de um método discursivo encontrados nas linhas artusianas que asseguraram o sucesso editorial naquele momento aos dias de hoje. Palavras-chave: análise do discurso; culinária; autoria; Pellegrino Artusi; Itália. Keywords: discourse analysis; culinary; authorship; Pellegrino Artusi; Italy. 